\title{
An updated view of the pathogenesis of steroid-sensitive nephrotic syndrome
}

\author{
Tomoko Horinouchi ${ }^{1} \cdot$ Kandai Nozu $^{1} \cdot$ Kazumoto lijima ${ }^{2,3}$
}

Received: 8 September 2021 / Revised: 1 November 2021 / Accepted: 24 November 2021 / Published online: 10 January 2022

(c) The Author(s) 2022

\begin{abstract}
Idiopathic nephrotic syndrome is the most common childhood glomerular disease. Most forms of this syndrome respond to corticosteroids at standard doses and are, therefore, defined as steroid-sensitive nephrotic syndrome (SSNS). Immunological mechanisms and subsequent podocyte disorders play a pivotal role in SSNS and have been studied for years; however, the precise pathogenesis remains unclear. With recent advances in genetic techniques, an exhaustive hypothesis-free approach called a genome-wide association study (GWAS) has been conducted in various populations. GWASs in pediatric SSNS peaked in the human leukocyte antigen class II region in various populations. Additionally, an association of immunerelated CALHM6/FAM26F, PARM1, BTNL2, and TNFSF15 genes, as well as NPHS1, which encodes nephrin expressed in podocytes, has been identified as a locus that achieves genome-wide significance in pediatric SSNS. However, the specific mechanism of SSNS development requires elucidation. This review describes an updated view of SSNS pathogenesis from immunological and genetic aspects, including interactions with infections or allergies, production of circulating factors, and an autoantibody hypothesis.
\end{abstract}

Keywords Steroid-sensitive nephrotic syndrome $\cdot$ Immune system $\cdot$ HLA class II $\cdot$ Podocyte disorders $\cdot$ NPHSI . Autoantibody

\section{Introduction}

Idiopathic nephrotic syndrome (NS) is the most common childhood glomerular disease. The incidence of this syndrome has been reported to be $1.15-16.9 / 100,000$ children, and it is highest in non-Western countries [1]. Most of these patients are initially treated with corticosteroids and fall into one of the following two broad categories: steroid-sensitive nephrotic syndrome (SSNS) and steroid-resistant nephrotic syndrome (SRNS), in which corticosteroids induce and do not induce remission, respectively [2]. In SRNS, abnormalities in podocyte-associated genes have been identified in

Kazumoto Iijima

iijima@med.kobe-u.ac.jp

1 Department of Pediatrics, Kobe University Graduate School of Medicine, Kobe, Japan

2 Hyogo Prefectural Kobe Children's Hospital, Kobe, Japan

3 Department of Advanced Pediatric Medicine, Kobe University Graduate School of Medicine, Minatojimaminami-machi 1-6-7, Chuo-ku, Kobe 650-0047, Japan approximately $30 \%$ of patients [3-5], and the mechanism of pathogenesis associated with structural abnormalities appears to be the most relevant. Conversely, immunological mechanisms and subsequent podocyte disorders have been considered [1]. Although genetic research, including genome-wide association study (GWAS), has improved the understanding of these mechanisms, the precise pathophysiology of SSNS remains elusive. In this review, we describe an updated view of SSNS pathogenesis from immunological and genetic aspects, including interactions with infections or allergies, production of circulating factors, and an autoantibody hypothesis.

\section{Immunological aspects of SSNS}

\section{T cell theory}

The pivotal role of prednisolone and the efficacy of immunosuppressive agents in SSNS treatment strongly implicate the immune system in the pathogenesis of the disease. The involvement of $\mathrm{T}$ cells in nephrotic syndrome (NS) was 
reported in the 1970s [6]. The main basis of this T cell theory is as follows: (1) there is an absence of routine deposition of immunoglobulins or complement in the glomeruli, suggesting the involvement of humoral factors; (2) immunosuppressants that suppress $\mathrm{T}$ cell function (corticosteroids, ciclosporin, and cyclophosphamide) are effective; and (3) some cases achieve remission following measles infection, which impairs T-cell function [7]. After the 1970s, the following relationships between NS and T cells were reported: upregulation of $\mathrm{CD} 8+$ cytotoxic $\mathrm{T}$ cells with downregulation of CD4 + T helper (Th) cells, an imbalance between Th2 and Th1 cells resulting in Th2 upregulation, and an imbalance between regulatory T cells and Th17 cells resulting in the prevalence of Th17 cells (reviewed in [8]). However, because of the heterogeneity of NS, these results were not replicable and did not account for all of its pathologies.

\section{B cell theory}

Based on the highly effective therapeutic effects of B celldepleting monoclonal antibody rituximab (RTX) $[9,10]$, the hypothesis that $\mathrm{B}$ cells are associated with disease was proposed in the 2010s. RTX is a chimeric anti-CD20 monoclonal antibody initially developed to treat B-cell non-Hodgkin lymphoma [11]. CD20 is expressed on the surface of all B cells from the pro-B phase until they eventually differentiate into plasma cells. The parallel occurrence of B cell depletion and a decrease in disease activity in NS strongly suggests a direct involvement of B cell pathology [12, 13]. Moreover, the lymphocyte subset most associated with relapse after RTX administration are switched memory B cells [14]. Additionally, mycophenolate mofetil, useful in preventing the recurrence of SSNS, suppresses switched memory B cells dominantly, suggesting that B cells are also involved in its pathogenesis [15]. Another possible mechanism for the efficacy of RTX in controlling NS is its direct action on the glomeruli or T cells. Various immunosuppressive agents act not only on immune cells but also directly on podocytes [16]. RTX also binds to acid sphingomyelinase-like phosphodiesterase $3 \mathrm{~b}$, which is expressed in glomerular epithelial cells [17]. However, ofatumumab, a humanized anti-CD20 monoclonal antibody with different corresponding epitopes, is also effective in patients with SSNS [18]. Therefore, the direct effect of RTX is thought to be exerted via B cells. B cells also interact with $T$ cells in general antigen presentation; accordingly, the immune system is extremely intertwined so that both cell types cannot be separated.

\section{CD80 and human leukocyte antigen class II}

CD80 (B7-1), important for B-cell and T-cell interaction, has attracted considerable attention because of its association with SSNS. CD80 is a transmembrane protein expressed in activated B cells and antigen-presenting cells. During antigen presentation, CD80 binds to CD28 on Th cells or cytotoxic T-lymphocyte-associated-4 on Treg cells and controls the activation or inactivation of T cells [19] (Fig. 1). Although podocytes are highly differentiated glomerularspecific cells, they express CD80 and possess immunogenic aspects [20-24] (Fig. 1). However, it is unclear whether urinary CD80 is useful in differentiating minimal change disease and focal segmental glomerular sclerosis or cytotoxic T-lymphocyte-associated-Ig is effective in refractory NS [25-27]. Podocytes express human leukocyte antigen (HLA) class II and function as immune cells [21]. HLA is a cell-surface molecule that presents specific antigen peptides to the host immune system, such as T cells [28]. Aberrant expression of HLA class II causes autoimmune diseases in antigen-presenting cells and various organs [29]. These facts suggest that podocytes can act as immune cells in the pathogenesis of NS.

\section{Circulating factors}

The pathophysiological role of circulating factors in NS has been suggested, especially in patients with focal segmental glomerulosclerosis (reviewed in [30,31]). The involvement of circulating factors has been demonstrated by trying to identify a substance from the serum of patients, proving that it induces urinary protein in animal models, and examining the effect on podocytes or endothelial cells, among others. The recurrence of NS in patients with focal segmental

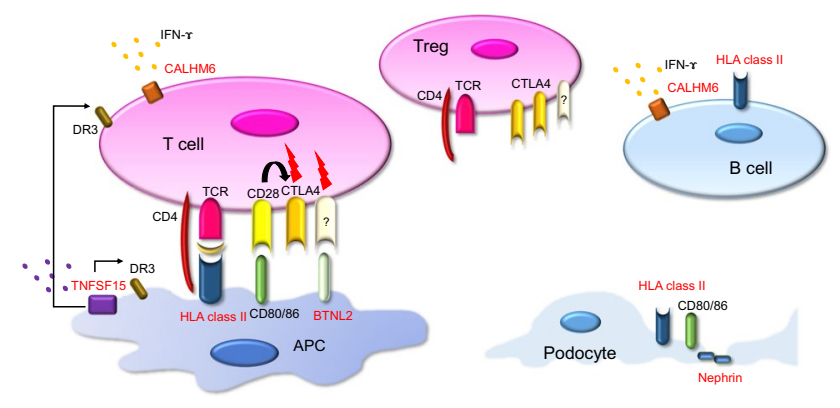

Fig. 1 Molecules possibly involved in the pathogenesis of SSNS. The molecules identified in the genome-wide association studies are highlighted in red. HLA class II molecules present antigens mainly in APCs and B cells, but they are also expressed in podocytes. BTNL2 shares a common structure with CD 80/86 and may be involved in $\mathrm{T}$ cell regulation. CALHM6 is expressed in various lymphocytes and releases cytokines such as IFN- $\gamma$. TNFSF15 interacts with death receptor 3 and activates immune cells. Nephrin is a key component of the slit diaphragm in podocytes. APC, antigen-presenting cell; TCR, $\mathrm{T}$ cell receptor; Treg, regulatory $\mathrm{T}$ cell; $B T N L 2$, butyrophilin-like 2; CTLA4, cytotoxic T-lymphocyte-associated-4; IFN- $\gamma$, interferongamma; TNFSF 15, tumor necrosis factor superfamily member 15; DR3, death receptor 3; Flash, some signals related to T cell differentiation 
glomerulosclerosis after kidney transplantation from unaffected donors strongly suggests the existence of circulating factors [32]. In patients with minimal change disease, interaction with vascular permeability factor derived from $\mathrm{T}$ cells or hemopexin has been indicated [31]. Activated hemopexin has been identified in patients with recurrent $\mathrm{MCD}$, and it has also been reported that hemopexin induces transient urinary protein in rats $[33,34]$. A certain number of patients are thought to have NS caused by circulating factors [35], but there is no conclusion on how many whose SSNS is attributed to circulating factors or what the specific circulating factor is.

\section{Interaction with infection}

The role of infection as a trigger for the onset or relapse of SSNS has been suggested [36, 37]. Dossier et al. investigated the prevalence of herpes viruses at the onset of childhood NS [38]. They measured the amount of Epstein-Barr virus (EBV), cytomegalovirus (CMV), human herpesvirus 6, and human herpesvirus 7 in peripheral blood and specific antibodies against EBV and CMV. They found that the prevalence of EBV DNA was higher in patients at the onset of NS than in controls.

EBV persists in circulating memory B cells without virion production by establishing latency [39]. How EBV latency affects B cells remains elusive, but it is associated with the risk of developing various autoimmune diseases [40]. EBV downregulates CD74, which may be a way of avoiding HLA class II antigen presentation and consequent CD4 + Th cell recognition while latent in B cells [41]. EBV survival strategies can alter B cells, and their effects can determine SSNS disease susceptibility.

\section{Interaction with allergy}

Many studies have investigated the association between SSNS and allergic diseases such as asthma, atopic dermatitis, or hay fever (reviewed in [42]). Wei et al. reported that patients in the cohort with atopic dermatitis had twice the incidence of NS [43]. Elevated serum IgE levels are known to be a trigger in allergic diseases, and a previous study showed that some patients with NS also have elevated IgE levels [44]. At present, the prevailing view is that common pathogenesis exists between allergic disease and SSNS rather than NS caused solely by allergic diseases [42]. Allergy-causing IgE is produced by B cells, and it is known that allergy is caused by Th2 activation due to Th2/ Th1 imbalance; this may coexist with the $\mathrm{T}$ cell and $\mathrm{B}$ cell theories described above. However, no clear, direct pathology has been established.

\section{Genetic aspects of SSNS}

\section{Variants in a single causative gene}

Advances in genetics have played a major role in the pathogenesis of NS. Approximately $30 \%$ of patients with SRNS have a single causative gene associated with podocytes [3-5]. SSNS and SRNS appear to be on the same spectrum and overlap because patients with SSNS may develop steroid resistance during the disease and may partially respond to immunosuppressant therapy, even if genetic abnormalities are identified [45, 46]. A combination of linkage analysis and whole-exome sequencing identified EMP2 mutations in SSNS [47]. Recently, six genes associated with Rholike small guanosine triphosphate-binding enzyme activity (MAGI2, TNS2, DLC1, CDK20, ITSN1, and ITSN2) were identified as causes of NS that can partially respond to steroids [48]. However, such variants in a single causative gene account for only a few families in SSNS. Most SSNS cases are considered to be multifactorial, and several reports have clarified susceptibility genes in SSNS [49-53] (reviewed in [54]).

\section{GWAS for clarifying susceptibility genes}

GWAS is a research method for clarifying single-nucleotide polymorphisms (SNPs) related to disease susceptibility genes by comprehensively examining and comparing SNPs as polymorphic markers between case and control groups [55]. Chromosomal recombination is repeated throughout a generation, resulting in genotypes similar to those of adjacent SNPs. Consequently, the genotypes of SNPs nearby tend to have a non-independent distribution in the population, which is called linkage disequilibrium [56]. In GWASs, the use of this property to impute tens of millions of SNPs across the whole genome from hundreds of thousands of SNPs genotyped by microarrays is common [57].

\section{HLA class II region}

Gbadegesin et al., using hypothesis-free exome-wide study methods, first showed that the $H L A-D Q$ region was significantly associated with SSNS in children in a South Asian population (Table 1) [49]. The $H L A-D R / D Q$ gene encodes an HLA class II molecule required for antigen presentation by antigen-presenting cells or B cells (Fig. 1). In 2018, Jia et al. showed that the most significant association in the $H L A-D R / D Q$ region was observed in Japanese childhood SSNS using GWAS methods (Table 1) [52]. In 2018, Debiec et al. also found SSNS-associated SNPs in the $H L A-D R / D Q$ region due to a trans-ethnic GWAS from 
Table 1 Genetic aspects of SSNS

\begin{tabular}{|c|c|c|c|c|c|c|c|}
\hline $\begin{array}{l}\text { Discovery study } \\
\text { (case) }\end{array}$ & $\begin{array}{l}\text { Replication } \\
\text { study }\end{array}$ & $\begin{array}{l}\text { Trans-ethnic } \\
\text { meta-analysis }\end{array}$ & HLA region & HLA type* & $\begin{array}{l}\text { Out of HLA } \\
\text { region }\end{array}$ & $\begin{array}{l}\text { Functional } \\
\text { analysis }\end{array}$ & Reference \\
\hline $\begin{array}{l}\text { South Asian } \\
\quad(n=214)\end{array}$ & N/A & N/A & $H L A-D Q$ & N/A & N/A & N/A & $\begin{array}{l}\text { Gbadegesin et al. } \\
2015\end{array}$ \\
\hline $\begin{array}{l}\text { Japanese } \\
\quad(n=224)\end{array}$ & Japanese & N/A & $H L A-D R / D Q$ & $\begin{array}{l}H L A- \\
\quad D R B 1 * 08: 02- \\
D Q B 1 * 03: 02\end{array}$ & N/A & N/A & Jia et al. 2018 \\
\hline $\begin{array}{l}\text { European } \\
\quad(n=132), \\
\text { African } \\
(n=56), \\
\text { Maghrebian } \\
(n=85)\end{array}$ & European & $\begin{array}{l}\text { European, Afri- } \\
\text { can, Maghre- } \\
\text { bian }\end{array}$ & $H L A-D R / D Q$ & $\begin{array}{l}H L A- \\
\quad D R B 1 * 07: 01- \\
D Q A 1 * 02: 01- \\
D Q B 1 * 02: 02\end{array}$ & $B T N L 2$ & eQTLs $(H L A)$ & Debiec et al. 2018 \\
\hline $\begin{array}{l}\text { European } \\
\quad(n=422)\end{array}$ & N/A & N/A & $H L A-D R / D Q$ & $\begin{array}{l}H L A- \\
\quad D Q A 1 * 02: 01\end{array}$ & $\begin{array}{l}\text { CALHM6/ } \\
\text { FAM26F } \\
\text { PARM1 }\end{array}$ & $\begin{array}{l}\text { eQTLs } \\
\qquad(C A L H M O)\end{array}$ & Dufek et al. 2019 \\
\hline $\begin{array}{l}\text { Japanese } \\
\quad(n=987)\end{array}$ & $\begin{array}{l}\text { Korean, South } \\
\text { Asian, African }\end{array}$ & $\begin{array}{l}\text { Japanese, } \\
\text { Korean, South } \\
\text { Asian, Afri- } \\
\text { can, European, } \\
\text { Hispanic, } \\
\text { Maghrebian }\end{array}$ & $H L A-D R / D Q$ & $\begin{array}{l}H L A- \\
\quad D R B 1 * 08: 02- \\
\quad D Q B 1 * 03: 02\end{array}$ & $\begin{array}{l}\text { NPHS1-KIR- } \\
\quad \text { REL2 } \\
\text { TNFSF15 }\end{array}$ & $\begin{array}{l}\text { Allele-specific } \\
\text { expression } \\
(N P H S 1) \\
\text { mRNA } \\
\text { expression } \\
\text { (TNFSF15) }\end{array}$ & Jia et al. 2020 \\
\hline
\end{tabular}

*Allele or haplotype with strongest association

${ }^{\$}$ Exome-wide association study

European cohorts (Table 1) [50]. HLA class II regions are highly polymorphic because of their natural selection against various pathogens [58]. Additionally, adaptation to infection has also been reported to contribute to the development of autoimmune diseases including multiple sclerosis and systemic lupus erythematosus [59]. A high polymorphism in the HLA class II region causes difficulty in imputation. Moreover, because $H L A-D Q$ and $H L A-D R$ regions have a strong linkage disequilibrium relationship, assessing which $H L A-D Q$ and $H L A-D R$ regions define true disease susceptibility is difficult. Using new HLA imputation methods [60] and genotyping, Jia et al. showed that $H L A-D R B 1 * 08: 02-D Q B 1 * 03: 02$ was the most significant genetic susceptibility factor [52]. In addition to identifying the relevant SNPs, identifying the actual disease susceptibility alleles may be essential for clarifying the subsequent pathophysiology.

Furthermore, expression quantitative trait loci (eQTL) analysis is a powerful tool to investigate the relationship between protein or mRNA expression levels and SNPs. For eQTL analysis, databases such as the international GTEx project and NephQTL specializing in kidney tissue (glomerulus and tubulointerstitium) can be used [61, 62]. Debiec et al. investigated the glomerular eQTL of identified SNPs and found that SSNS-associated SNPs (rs1063348) decreased the expression of HLA-DRB1, $H L A-D R B 5$, and HLA-DQBI [50].

\section{Outside of the HLA class II region (immune-related)}

Dufek et al. reported that, in addition to the strongest association in the $H L A-D R / D Q$ region, CALHM6/FAM26F and $P A R M 1$ were loci that achieved genome-wide significance (Table 1) [51]. In addition, BTNL2 and TNFSF15 were identified by Debiec et al. and Jia et al., respectively, as susceptibility genes for SSNS [50, 53]. CALHM6/FAM26F and $P A R M 1$ are related to immunity, even though they are outside the HLA class II region. BTNL2 encodes the HLA class II-associated transmembrane protein, butyrophilinlike 2 (BTNL2), which is a member of the immunoglobulin superfamily and is implicated as a costimulatory molecule involved in $\mathrm{T}$ cell modulation, based on its homology with B7-1 (CD80) (Fig. 1) [63]. Signals mediated by BTNL2 induce FoxP3 and expedite differentiation of naïve $\mathrm{T}$ cells into regulatory T cells [64]. BTNL2 is expressed at the highest levels in the intestine and is involved in intestinal immunity [65]. Moreover, BTNL2 is a disease susceptibility gene for many autoimmune diseases, such as sarcoidosis, ulcerative colitis, systemic lupus erythematosus, and rheumatoid arthritis [66] (reviewed in [63]).

CALHM6/FAM26F encodes calcium homeostasis modulator family member 6 (CALHM6), previously called a family with sequence similarity 26, member F (FAM26F) [67]. CALHM6 is a transmembrane protein expressed in various immune cells and plays an important role in diverse immune 
responses (Fig. 1) [68]. Specific cell-cell interactions and their roles remain unclear but likely to contribute to interferon- $\gamma$ secretion [69]. The lead SNP (rs2637678) identified by Dufek et al. showed a strong eQTL for CALHM6, and the risk allele decreased the expression of CALHM6 [51]. Although they did not conduct replication analysis, they identified the same SNP (rs2858829) as that identified by Debiec et al. as a marginal genome-wide significant SNP in a region near CALHM6 [50]. Therefore, the involvement of this region has been demonstrated in multiple datasets.

TNFSF 15 encodes tumor necrosis factor superfamily member 15 (TNFSF15), which interacts with death receptor 3 , promotes inflammatory responses in human macrophages, and is associated with apoptosis, cell proliferation, and polarization to Th1 and Th17 cells [70]. Serum TNFSF15 levels are significantly increased in inflammatory bowel disease and primary biliary cirrhosis [71, 72]. Jia et al. discovered a genome-wide significant association in the TNFSF 15 region. One of its replicated SNPs (rs4979462) was also known to be associated with susceptibility to primary biliary cirrhosis, which affected mRNA expression [73]. The mechanism by which these alterations cause NS is unclear, but the immune balance may be altered.

\section{Outside of the HLA class II region (podocyte-related)}

In addition to the $H L A-D R / D Q$ region, Jia et al. identified genome-wide significant variants in the NPHS1-KIRREL2 region (rs56117924) in an extended GWAS in Japanese childhood SSNS [53]. Jia et al. also conducted a replication study, and significant associations were replicated in Korean, South Asian, and African populations [53]. Additionally, a trans-ethnic meta-analysis of Japanese, Korean, South Asian, African, Hispanic, European, and Maghrebian populations showed genome-wide significant associations of variants in the NPHS1-KIRREL2 region (rs2285450 and rs2073901) [53]. The SNPs rs2285450 (NPHS1 NM_004646.4: c.294C > T) and rs2073901 (NPHS1 NM_004646.4: c. $2223 \mathrm{C}>\mathrm{T}$ ) are synonymous variants of the NPHSI gene in exons 3 and 17, respectively. NPHSI encodes nephrin, a molecule located in the slit diaphragm between the foot processes of podocytes (Fig. 1) [74], and is the causative gene of congenital NS Finnish type and SRNS [3-5]. Although there is no evidence that these synonymous variants act as eQTLs, RNA sequencing data allowed the observation of significant allele-specific expression, resulting in lower NPHS1 expression in haplotypes with risk alleles [53]. Future studies must examine why such allele-specific expression occurs and how it causes SSNS. Findings reported by Jia et al. showed that the gene responsible for a monogenic rare disease (congenital NS Finnish type, SRNS) could be a susceptibility gene for a relatively common multifactorial disease (SSNS). Recently, such a wide range of mutations in a single gene has received much attention [75, 76].

\section{Functional study}

The next challenge is to clarify the significance of disease susceptibility variants detected by GWAS, that is, the direct mechanism causing the disease. For the development of disease-specific therapies, it is highly desirable to elucidate the mechanism. As mentioned above, eQTL analysis about candidate SNPs has become widely used, but an analysis of the relationship between the eQTL and the pathogenesis is needed. Potential methods for further functional analysis include in vitro analysis or analysis using organoids constructed from iPS cells derived from patients (reviewed in [77]). In addition to 3D organoid construction, 2D organoid construction (glomerulus on a chip) is also in progress and could be applied to various related research [77]. In particular, it is often difficult to obtain fresh samples (e.g., kidney biopsy samples) for RNA analysis, which can become an obstacle in clarifying pathogenesis. Therefore, combining such organoid construction technology and RNA-seq analysis may help elucidate SSNS pathogenesis.

\section{Perspectives}

Although the pathogenesis of SSNS has not been clarified, the autoantibody hypothesis has recently been a focus. Many diseases in which HLA class II is identified as a disease susceptibility gene are autoimmune diseases associated with autoantibody [78-80]. In membranous nephropathy, associated with massive proteinuria and which is common in adults, PLA2R and HLA-DQA1 regions are disease susceptibility genes [81]. An autoantibody reactive with the M-type phospholipase A2 receptor encoded by the PLA2R gene is associated with membranous nephropathy [82]. As mentioned above, NPHS1 encoding nephrin is a susceptibility gene; therefore, anti-nephrin antibodies may be involved in some patients with SSNS. In animal models, anti-nephrin antibodies cause NS [83]. Recently, Watts et al. reported that circulating autoantibodies against nephrin were detected in approximately $30 \%$ of patients with minimal change disease. The anti-nephrin antibody titer was correlated with disease activity [84]. Moreover, autoantibodies against molecules related to podocytes other than nephrin have been identified in some patients with NS $[85,86]$. Conclusively, future research to clarify the pathogenesis of SSNS is expected based on the knowledge derived from hypothesis-free genetic techniques. 
Acknowledgements We thank Ellen Knapp, PhD, from Edanz (https:// edanz.com/ac) for editing the draft of this manuscript.

Author contribution $\mathrm{TH}$ drafted the manuscript; $\mathrm{KN}$ and $\mathrm{KI}$ reviewed the manuscript. All authors read and approved the final manuscript.

Data availability Not applicable.

Code availability Not applicable.

\section{Declarations}

Ethics approval Not applicable.

Consent to participate Not applicable.

Consent for publication Not applicable.

Competing interests The authors declare no competing interests.

Open Access This article is licensed under a Creative Commons Attribution 4.0 International License, which permits use, sharing, adaptation, distribution and reproduction in any medium or format, as long as you give appropriate credit to the original author(s) and the source, provide a link to the Creative Commons licence, and indicate if changes were made. The images or other third party material in this article are included in the article's Creative Commons licence, unless indicated otherwise in a credit line to the material. If material is not included in the article's Creative Commons licence and your intended use is not permitted by statutory regulation or exceeds the permitted use, you will need to obtain permission directly from the copyright holder. To view a copy of this licence, visit http://creativecommons.org/licenses/by/4.0/.

\section{References}

1. Noone DG, Iijima K, Parekh R (2018) Idiopathic nephrotic syndrome in children. Lancet 392:61-74. https://doi.org/10.1016/ s0140-6736(18)30536-1

2. Eddy AA, Symons JM (2003) Nephrotic syndrome in childhood. Lancet 362:629-639. https://doi.org/10.1016/S0140-6736(03) 14184-0

3. Sadowski CE, Lovric S, Ashraf S, Pabst WL, Gee HY, Kohl S, Engelmann S, Vega-Warner V, Fang H, Halbritter J, Somers MJ, Tan W, Shril S, Fessi I, Lifton RP, Bockenhauer D, El-Desoky S, Kari JA, Zenker M, Kemper MJ, Mueller D, Fathy HM, Soliman NA, Hildebrandt F (2015) A single-gene cause in $29.5 \%$ of cases of steroid-resistant nephrotic syndrome. J Am Soc Nephrol 26:1279-1289. https://doi.org/10.1681/asn.2014050489

4. Santín S, Bullich G, Tazón-Vega B, García-Maset R, Giménez I, Silva I, Ruíz P, Ballarín J, Torra R, Ars E (2011) Clinical utility of genetic testing in children and adults with steroid-resistant nephrotic syndrome. Clin J Am Soc Nephrol 6:1139-1148. https:// doi.org/10.2215/cjn.05260610

5. Nagano C, Yamamura T, Horinouchi T, Aoto Y, Ishiko S, Sakakibara N, Shima Y, Nakanishi K, Nagase H, Iijima K, Nozu K (2020) Comprehensive genetic diagnosis of Japanese patients with severe proteinuria. Sci Rep 10:270. https://doi.org/10.1038/ s41598-019-57149-5

6. Shalhoub RJ (1974) Pathogenesis of lipoid nephrosis: a disorder of T-cell function. Lancet 2:556-560
7. Lin CY, Hsu HC (1986) Histopathological and immunological studies in spontaneous remission of nephrotic syndrome after intercurrent measles infection. Nephron 42:110-115. https://doi. org/10.1159/000183647

8. Colucci M, Corpetti G, Emma F, Vivarelli M (2018) Immunology of idiopathic nephrotic syndrome. Pediatr Nephrol 33:573-584. https://doi.org/10.1007/s00467-017-3677-5

9. Iijima K, Sako M, Nozu K, Mori R, Tuchida N, Kamei K, Miura K, Aya K, Nakanishi K, Ohtomo Y, Takahashi S, Tanaka R, Kaito H, Nakamura H, Ishikura K, Ito S, Ohashi Y (2014) Rituximab for childhood-onset, complicated, frequently relapsing nephrotic syndrome or steroid-dependent nephrotic syndrome: a multicentre, double-blind, randomised, placebo-controlled trial. Lancet 384:1273-1281. https://doi.org/10.1016/s0140-6736(14)60541-9

10. Ravani P, Magnasco A, Edefonti A, Murer L, Rossi R, Ghio L, Benetti E, Scozzola F, Pasini A, Dallera N, Sica F, Belingheri M, Scolari F, Ghiggeri GM (2011) Short-term effects of rituximab in children with steroid- and calcineurin-dependent nephrotic syndrome: a randomized controlled trial. Clin J Am Soc Nephrol 6:1308-1315. https://doi.org/10.2215/cjn.09421010

11. Maloney DG, Grillo-López AJ, White CA, Bodkin D, Schilder RJ, Neidhart JA, Janakiraman N, Foon KA, Liles TM, Dallaire BK, Wey K, Royston I, Davis T, Levy R (1997) IDEC-C2B8 (rituximab) anti-CD20 monoclonal antibody therapy in patients with relapsed low-grade non-Hodgkin's lymphoma. Blood 90:2188-2195

12. Kamei K, Ito S, Nozu K, Fujinaga S, Nakayama M, Sako M, Saito M, Yoneko M, Iijima K (2009) Single dose of rituximab for refractory steroid-dependent nephrotic syndrome in children. Pediatr Nephrol 24:1321-1328. https://doi.org/10.1007/ s00467-009-1191-0

13. Sellier-Leclerc AL, Macher MA, Loirat C, Guérin V, Watier H, Peuchmaur M, Baudouin V, Deschênes G (2010) Rituximab efficiency in children with steroid-dependent nephrotic syndrome. Pediatr Nephrol 25:1109-1115. https://doi.org/10.1007/ s00467-010-1465-6

14. Colucci M, Carsetti R, Cascioli S, Casiraghi F, Perna A, Ravà L, Ruggiero B, Emma F, Vivarelli M (2016) B cell reconstitution after rituximab treatment in idiopathic nephrotic syndrome. J Am Soc Nephrol 27:1811-1822. https://doi.org/10.1681/asn.20150 50523

15. Bashford-Rogers RJM, Bergamaschi L, McKinney EF, Pombal DC, Mescia F, Lee JC, Thomas DC, Flint SM, Kellam P, Jayne DRW, Lyons PA, Smith KGC (2019) Analysis of the B cell receptor repertoire in six immune-mediated diseases. Nature 574:122126. https://doi.org/10.1038/s41586-019-1595-3

16. Yoo TH, Fornoni A (2015) Nonimmunologic targets of immunosuppressive agents in podocytes. Kidney Res Clin Pract 34:69-75. https://doi.org/10.1016/j.krcp.2015.03.003

17. Fornoni A, Sageshima J, Wei C, Merscher-Gomez S, AguillonPrada R, Jauregui AN, Li J, Mattiazzi A, Ciancio G, Chen L, Zilleruelo G, Abitbol C, Chandar J, Seeherunvong W, Ricordi C, Ikehata M, Rastaldi MP, Reiser J, Burke GW 3rd (2011) Rituximab targets podocytes in recurrent focal segmental glomerulosclerosis. Sci Transl Med 3:85ra46. https://doi.org/10.1126/scitr anslmed.3002231

18. Vivarelli M, Colucci M, Bonanni A, Verzani M, Serafinelli J, Emma F, Ghiggeri G (2017) Ofatumumab in two pediatric nephrotic syndrome patients allergic to rituximab. Pediatr Nephrol 32:181-184. https://doi.org/10.1007/s00467-016-3498-y

19. Alegre ML, Frauwirth KA, Thompson CB (2001) T-cell regulation by CD28 and CTLA-4. Nat Rev Immunol 1:220-228. https:// doi.org/10.1038/35105024

20. Reiser J, von Gersdorff G, Loos M, Oh J, Asanuma K, Giardino L, Rastaldi MP, Calvaresi N, Watanabe H, Schwarz K, Faul C, Kretzler M, Davidson A, Sugimoto H, Kalluri R, Sharpe AH, 
Kreidberg JA, Mundel P (2004) Induction of B7-1 in podocytes is associated with nephrotic syndrome. J Clin Invest 113:1390-1397. https://doi.org/10.1172/jci20402

21. Goldwich A, Burkard M, Olke M, Daniel C, Amann K, Hugo C, Kurts C, Steinkasserer A, Gessner A (2013) Podocytes are nonhematopoietic professional antigen-presenting cells. J Am Soc Nephrol 24:906-916. https://doi.org/10.1681/asn.2012020133

22. Cai M, Zhou T, Wang X, Shang M, Zhang Y, Luo M, Xu C, Yuan W (2016) DC-SIGN expression on podocytes and its role in inflammatory immune response of lupus nephritis. Clin Exp Immunol 183:317-325. https://doi.org/10.1111/cei.12723

23. Cara-Fuentes G, Venkatareddy M, Verma R, Segarra A, Cleuren AC, Martínez-Ramos A, Johnson RJ, Garg P (2020) Glomerular endothelial cells and podocytes can express CD80 in patients with minimal change disease during relapse. Pediatr Nephrol 35:18871896. https://doi.org/10.1007/s00467-020-04541-3

24. Reiser J, Mundel P (2004) Danger signaling by glomerular podocytes defines a novel function of inducible B7-1 in the pathogenesis of nephrotic syndrome. J Am Soc Nephrol 15:2246-2248. https://doi.org/10.1097/01.Asn.0000136312.46464.33

25. Minamikawa S, Nozu K, Maeta S, Yamamura T, Nakanishi K, Fujimura J, Horinouchi T, Nagano C, Sakakibara N, Nagase H, Shima H, Noda K, Ninchoji T, Kaito H, Iijima K (2018) The utility of urinary CD80 as a diagnostic marker in patients with renal diseases. Sci Rep 8:17322. https://doi.org/10.1038/ s41598-018-35798-2

26. Yu CC, Fornoni A, Weins A, Hakroush S, Maiguel D, Sageshima J, Chen L, Ciancio G, Faridi MH, Behr D, Campbell KN, Chang JM, Chen HC, Oh J, Faul C, Arnaout MA, Fiorina P, Gupta V, Greka A, Burke GW 3rd, Mundel P (2013) Abatacept in B7-1-positive proteinuric kidney disease. N Engl J Med 369:2416-2423. https://doi.org/10.1056/NEJMoa1304572

27. Gonzalez Guerrico AM, Lieske J, Klee G, Kumar S, Lopez-Baez V, Wright AM, Bobart S, Shevell D, Maldonado M, Troost JP, Hogan MC (2020) Urinary CD80 discriminates among glomerular disease types and reflects disease activity. Kidney Int Rep 5:2021-2031. https://doi.org/10.1016/j.ekir.2020.08.001

28. Neefjes J, Jongsma ML, Paul P, Bakke O (2011) Towards a systems understanding of MHC class I and MHC class II antigen presentation. Nat Rev Immunol 11:823-836. https://doi.org/10. 1038/nri3084

29. Arase N, Arase H (2015) Cellular misfolded proteins rescued from degradation by MHC class II molecules are possible targets for autoimmune diseases. J Biochem 158:367-372. https://doi.org/ $10.1093 / \mathrm{jb} / \mathrm{mvv093}$

30. Davin JC (2016) The glomerular permeability factors in idiopathic nephrotic syndrome. Pediatr Nephrol 31:207-215. https://doi.org/ 10.1007/s00467-015-3082-x

31. McCarthy ET, Sharma M, Savin VJ (2010) Circulating permeability factors in idiopathic nephrotic syndrome and focal segmental glomerulosclerosis. Clin J Am Soc Nephrol 5:2115-2121. https:// doi.org/10.2215/cjn.03800609

32. Fine RN (2007) Recurrence of nephrotic syndrome/focal segmental glomerulosclerosis following renal transplantation in children. Pediatr Nephrol 22:496-502. https://doi.org/10.1007/ s00467-006-0361-6

33. Bakker WW, van Dael CM, Pierik LJ, van Wijk JA, Nauta J, Borghuis T, Kapojos JJ (2005) Altered activity of plasma hemopexin in patients with minimal change disease in relapse. Pediatr Nephrol 20:1410-1415. https://doi.org/10.1007/s00467-005-1936-3

34. Cheung PK, Klok PA, Baller JF, Bakker WW (2000) Induction of experimental proteinuria in vivo following infusion of human plasma hemopexin. Kidney Int 57:1512-1520. https://doi.org/10. 1046/j.1523-1755.2000.00996.x
35. Saleem MA (2019) Molecular stratification of idiopathic nephrotic syndrome. Nat Rev Nephrol 15:750-765. https://doi.org/10.1038/ s41581-019-0217-5

36. MacDonald NE, Wolfish N, McLaine P, Phipps P, Rossier E (1986) Role of respiratory viruses in exacerbations of primary nephrotic syndrome. J Pediatr 108:378-382. https://doi.org/10. 1016/s0022-3476(86)80876-9

37. Yap HK, Han EJ, Heng CK, Gong WK (2001) Risk factors for steroid dependency in children with idiopathic nephrotic syndrome. Pediatr Nephrol 16:1049-1052. https://doi.org/10.1007/ s004670100024

38. Dossier C, Sellier-Leclerc AL, Rousseau A, Michel Y, GautheretDejean A, Englender M, Madhi F, Charbit M, Ulinski T, Simon T, Jacqz-Aigrain E, Deschenes G (2014) Prevalence of herpesviruses at onset of idiopathic nephrotic syndrome. Pediatr Nephrol 29:2325-2331. https://doi.org/10.1007/s00467-014-2860-1

39. Münz C (2019) Latency and lytic replication in Epstein-Barr virus-associated oncogenesis. Nat Rev Microbiol 17:691-700. https://doi.org/10.1038/s41579-019-0249-7

40. Niller HH, Wolf H, Ay E, Minarovits J (2011) Epigenetic dysregulation of Epstein-Barr virus latency and development of autoimmune disease. Adv Exp Med Biol 711:82-102. https://doi.org/10. 1007/978-1-4419-8216-2 7

41. Zuo J, Thomas WA, Haigh TA, Fitzsimmons L, Long HM, Hislop AD, Taylor GS, Rowe M (2011) Epstein-Barr virus evades CD4+ $\mathrm{T}$ cell responses in lytic cycle through BZLF1-mediated downregulation of CD74 and the cooperation of vBcl-2. PLoS Pathog 7:e1002455. https://doi.org/10.1371/journal.ppat.1002455

42. Zheng Y, Hou L, Wang XL, Zhao CG, Du Y (2021) A review of nephrotic syndrome and atopic diseases in children. Transl Androl Urol 10:475-482. https://doi.org/10.21037/tau-20-665

43. Wei CC, Tsai JD, Lin CL, Shen TC, Li TC, Chung CJ (2014) Increased risk of idiopathic nephrotic syndrome in children with atopic dermatitis. Pediatr Nephrol 29:2157-2163. https://doi.org/ 10.1007/s00467-014-2835-2

44. Tain YL, Chen TY, Yang KD (2003) Implication of serum IgE in childhood nephrotic syndrome. Pediatr Nephrol 18:1211-1215. https://doi.org/10.1007/s00467-003-1269-z

45. Hinkes B, Wiggins RC, Gbadegesin R, Vlangos CN, Seelow D, Nürnberg G, Garg P, Verma R, Chaib H, Hoskins BE, Ashraf S, Becker C, Hennies HC, Goyal M, Wharram BL, Schachter AD, Mudumana S, Drummond I, Kerjaschki D, Waldherr R, Dietrich A, Ozaltin F, Bakkaloglu A, Cleper R, Basel-Vanagaite L, Pohl M, Griebel M, Tsygin AN, Soylu A, Müller D, Sorli CS, Bunney TD, Katan M, Liu J, Attanasio M, O’Toole JF, Hasselbacher K, Mucha B, Otto EA, Airik R, Kispert A, Kelley GG, Smrcka AV, Gudermann T, Holzman LB, Nürnberg P, Hildebrandt F (2006) Positional cloning uncovers mutations in PLCE1 responsible for a nephrotic syndrome variant that may be reversible. Nat Genet 38:1397-1405. https://doi.org/10.1038/ng1918

46. Gellermann J, Stefanidis CJ, Mitsioni A, Querfeld U (2010) Successful treatment of steroid-resistant nephrotic syndrome associated with WT1 mutations. Pediatr Nephrol 25:1285-1289. https:// doi.org/10.1007/s00467-010-1468-3

47. Gee HY, Ashraf S, Wan X, Vega-Warner V, Esteve-Rudd J, Lovric S, Fang H, Hurd TW, Sadowski CE, Allen SJ, Otto EA, Korkmaz E, Washburn J, Levy S, Williams DS, Bakkaloglu SA, Zolotnitskaya A, Ozaltin F, Zhou W, Hildebrandt F (2014) Mutations in EMP2 cause childhood-onset nephrotic syndrome. Am J Hum Genet 94:884-890. https://doi.org/10.1016/j.ajhg.2014.04.010

48. Ashraf S, Kudo H, Rao J, Kikuchi A, Widmeier E, Lawson JA, Tan W, Hermle T, Warejko JK, Shril S, Airik M, Jobst-Schwan T, Lovric S, Braun DA, Gee HY, Schapiro D, Majmundar AJ, Sadowski CE, Pabst WL, Daga A, van der Ven AT, Schmidt JM, Low BC, Gupta AB, Tripathi BK, Wong J, Campbell K, Metcalfe K, Schanze D, Niihori T, Kaito H, Nozu K, Tsukaguchi H, 
Tanaka R, Hamahira K, Kobayashi Y, Takizawa T, Funayama R, Nakayama K, Aoki Y, Kumagai N, Iijima K, Fehrenbach H, Kari JA, El Desoky S, Jalalah S, Bogdanovic R, Stajic N, Zappel H, Rakhmetova A, Wassmer SR, Jungraithmayr T, Strehlau J, Kumar AS, Bagga A, Soliman NA, Mane SM, Kaufman L, Lowy DR, Jairajpuri MA, Lifton RP, Pei Y, Zenker M, Kure S, Hildebrandt $\mathrm{F}$ (2018) Mutations in six nephrosis genes delineate a pathogenic pathway amenable to treatment. Nat Commun 9:1960. https://doi. org/10.1038/s41467-018-04193-w

49. Gbadegesin RA, Adeyemo A, Webb NJ, Greenbaum LA, Abeyagunawardena A, Thalgahagoda S, Kale A, Gipson D, Srivastava T, Lin JJ, Chand D, Hunley TE, Brophy PD, Bagga A, Sinha A, Rheault MN, Ghali J, Nicholls K, Abraham E, Janjua HS, Omoloja A, Barletta GM, Cai Y, Milford DD, O'Brien C, Awan A, Belostotsky V, Smoyer WE, Homstad A, Hall G, Wu G, Nagaraj S, Wigfall D, Foreman J, Winn MP (2015) HLA-DQA1 and PLCG2 are candidate risk loci for childhood-onset steroidsensitive nephrotic syndrome. J Am Soc Nephrol 26:1701-1710. https://doi.org/10.1681/asn.2014030247

50. Debiec H, Dossier C, Letouze E, Gillies CE, Vivarelli M, Putler RK, Ars E, Jacqz-Aigrain E, Elie V, Colucci M, Debette S, Amouyel P, Elalaoui SC, Sefiani A, Dubois V, Simon T, Kretzler M, Ballarin J, Emma F, Sampson MG, Deschenes G, Ronco P (2018) Transethnic, genome-wide analysis reveals immune-related risk alleles and phenotypic correlates in pediatric steroid-sensitive nephrotic syndrome. J Am Soc Nephrol 29:2000-2013. https://doi. org/10.1681/asn.2017111185

51. Dufek S, Cheshire C, Levine AP, Trompeter RS, Issler N, Stubbs M, Mozere M, Gupta S, Klootwijk E, Patel V, Hothi D, Waters A, Webb H, Tullus K, Jenkins L, Godinho L, Levtchenko E, Wetzels J, Knoers N, Teeninga N, Nauta J, Shalaby M, Eldesoky S, Kari JA, Thalgahagoda S, Ranawaka R, Abeyagunawardena A, Adeyemo A, Kristiansen M, Gbadegesin R, Webb NJ, Gale DP, Stanescu HC, Kleta R, Bockenhauer D (2019) Genetic identification of two novel loci associated with steroid-sensitive nephrotic syndrome. J Am Soc Nephrol 30:1375-1384. https://doi.org/10. 1681/asn.2018101054

52. Jia X, Horinouchi T, Hitomi Y, Shono A, Khor SS, Omae Y, Kojima K, Kawai Y, Nagasaki M, Kaku Y, Okamoto T, Ohwada Y, Ohta K, Okuda Y, Fujimaru R, Hatae K, Kumagai N, Sawanobori E, Nakazato H, Ohtsuka Y, Nakanishi K, Shima Y, Tanaka R, Ashida A, Kamei K, Ishikura K, Nozu K, Tokunaga K, Iijima K (2018) Strong association of the HLA-DR/DQ locus with childhood steroid-sensitive nephrotic syndrome in the Japanese population. J Am Soc Nephrol 29:2189-2199. https://doi.org/10.1681/ asn.2017080859

53. Jia X, Yamamura T, Gbadegesin R, McNulty MT, Song K, Nagano C, Hitomi Y, Lee D, Aiba Y, Khor SS, Ueno K, Kawai Y, Nagasaki M, Noiri E, Horinouchi T, Kaito H, Hamada R, Okamoto T, Kamei K, Kaku Y, Fujimaru R, Tanaka R, Shima Y, Research Consortium on Genetics of Childhood Idiopathic Nephrotic Syndrome in Japan, Baek J, Kang HG, Ha IS, Han KH, Yang EM, Korean Consortium of Hereditary Renal Diseases in Children, Abeyagunawardena A, Lane B, Chryst-Stangl M, Esezobor C, Solarin A, Midwest Pediatric Nephrology Consortium (Genetics of Nephrotic Syndrome Study Group), Dossier C, Deschênes G, NEPHROVIR, Vivarelli M, Debiec H, Ishikura K, Matsuo M, Nozu K, Ronco P, Cheong HI, Sampson MG, Tokunaga K, Iijima $\mathrm{K}$ (2020) Common risk variants in NPHS1 and TNFSF15 are associated with childhood steroid-sensitive nephrotic syndrome. Kidney Int 98:1308-1322. https://doi.org/10.1016/j.kint.2020.05. 029

54. Dufek-Kamperis S, Kleta R, Bockenhauer D, Gale D, Downie ML (2021) Novel insights in the genetics of steroid-sensitive nephrotic syndrome in childhood. Pediatr Nephrol 36:2165-2175. https:// doi.org/10.1007/s00467-020-04780-4
55. Hirschhorn JN, Daly MJ (2005) Genome-wide association studies for common diseases and complex traits. Nat Rev Genet 6:95-108. https://doi.org/10.1038/nrg1521

56. Slatkin M (2008) Linkage disequilibrium — understanding the evolutionary past and mapping the medical future. Nat Rev Genet 9:477-485. https://doi.org/10.1038/nrg2361

57. Marchini J, Howie B, Myers S, McVean G, Donnelly P (2007) A new multipoint method for genome-wide association studies by imputation of genotypes. Nat Genet 39:906-913. https://doi.org/ $10.1038 /$ ng2088

58. Barreiro LB, Quintana-Murci L (2010) From evolutionary genetics to human immunology: how selection shapes host defence genes. Nat Rev Genet 11:17-30. https://doi.org/10.1038/nrg2698

59. Steri M, Orrù V, Idda ML, Pitzalis M, Pala M, Zara I, Sidore C, Faà V, Floris M, Deiana M, Asunis I, Porcu E, Mulas A, Piras MG, Lobina M, Lai S, Marongiu M, Serra V, Marongiu M, Sole G, Busonero F, Maschio A, Cusano R, Cuccuru G, Deidda F, Poddie F, Farina G, Dei M, Virdis F, Olla S, Satta MA, Pani M, Delitala A, Cocco E, Frau J, Coghe G, Lorefice L, Fenu G, Ferrigno P, Ban M, Barizzone N, Leone M, Guerini FR, Piga M, Firinu D, Kockum I, Lima Bomfim I, Olsson T, Alfredsson L, Suarez A, Carreira PE, Castillo-Palma MJ, Marcus JH, Congia M, Angius A, Melis M, Gonzalez A, Alarcón Riquelme ME, da Silva BM, Marchini M, Danieli MG, Del Giacco S, Mathieu A, Pani A, Montgomery SB, Rosati G, Hillert J, Sawcer S, D'Alfonso S, Todd JA, Novembre J, Abecasis GR, Whalen MB, Marrosu MG, Meloni A, Sanna S, Gorospe M, Schlessinger D, Fiorillo E, Zoledziewska M, Cucca F (2017) Overexpression of the cytokine BAFF and autoimmunity risk. N Engl J Med 376:1615-1626. https://doi.org/10.1056/NEJMoa1610528

60. Khor SS, Yang W, Kawashima M, Kamitsuji S, Zheng X, Nishida N, Sawai H, Toyoda H, Miyagawa T, Honda M, Kamatani N, Tokunaga K (2015) High-accuracy imputation for HLA class I and II genes based on high-resolution SNP data of population-specific references. Pharmacogenomics J 15:530-537. https://doi.org/10.1038/tpj.2015.4

61. GTEx Consortium (2020) The GTEx Consortium atlas of genetic regulatory effects across human tissues. Science 369:1318-1330. https://doi.org/10.1126/science.aaz1776

62. Gillies CE, Putler R, Menon R, Otto E, Yasutake K, Nair V, Hoover P, Lieb D, Li S, Eddy S, Fermin D, McNulty MT, Hacohen N, Kiryluk K, Kretzler M, Wen X, Sampson MG (2018) An eQTL landscape of kidney tissue in human nephrotic syndrome. Am J Hum Genet 103:232-244. https://doi.org/10.1016/j.ajhg. 2018.07.004

63. Arnett HA, Viney JL (2014) Immune modulation by butyrophilins. Nat Rev Immunol 14:559-569. https://doi.org/10.1038/ nri3715

64. Swanson RM, Gavin MA, Escobar SS, Rottman JB, Lipsky BP, Dube S, Li L, Bigler J, Wolfson M, Arnett HA, Viney JL (2013) Butyrophilin-like 2 modulates B7 costimulation to induce Foxp3 expression and regulatory $\mathrm{T}$ cell development in mature $\mathrm{T}$ cells. J Immunol 190:2027-2035. https://doi.org/10.4049/jimmunol. 1201760

65. Arnett HA, Escobar SS, Gonzalez-Suarez E, Budelsky AL, Steffen LA, Boiani N, Zhang M, Siu G, Brewer AW, Viney JL (2007) BTNL2, a butyrophilin/B7-like molecule, is a negative costimulatory molecule modulated in intestinal inflammation. J Immunol 178:1523-1533. https://doi.org/10.4049/jimmunol.178.3.1523

66. Valentonyte R, Hampe J, Huse K, Rosenstiel P, Albrecht M, Stenzel A, Nagy M, Gaede KI, Franke A, Haesler R, Koch A, Lengauer T, Seegert D, Reiling N, Ehlers S, Schwinger E, Platzer M, Krawczak M, Müller-Quernheim J, Schürmann M, Schreiber S (2005) Sarcoidosis is associated with a truncating splice site mutation in BTNL2. Nat Genet 37:357-364. https://doi.org/10. 1038/ng 1519 
67. Ebihara T, Azuma M, Oshiumi H, Kasamatsu J, Iwabuchi K, Matsumoto K, Saito H, Taniguchi T, Matsumoto M, Seya T (2010) Identification of a polyI:C-inducible membrane protein that participates in dendritic cell-mediated natural killer cell activation. J Exp Med 207:2675-2687. https://doi.org/10.1084/jem.20091573

68. Malik U, Javed A, Ali A, Asghar K (2017) Structural and functional annotation of human FAM26F: a multifaceted protein having a critical role in the immune system. Gene 597:66-75. https:// doi.org/10.1016/j.gene.2016.10.029

69. Kasamatsu J, Azuma M, Oshiumi H, Morioka Y, Okabe M, Ebihara T, Matsumoto M, Seya T (2014) INAM plays a critical role in IFN- $\gamma$ production by NK cells interacting with polyinosinic-polycytidylic acid-stimulated accessory cells. J Immunol 193:51995207. https://doi.org/10.4049/jimmunol.1400924

70. Sun R, Hedl M, Abraham C (2021) TNFSF15 promotes antimicrobial pathways in human macrophages and these are modulated by TNFSF15 disease-risk variants. Cell Mol Gastroenterol Hepatol 11:249-272. https://doi.org/10.1016/j.jcmgh.2020.08.003

71. Aiba Y, Harada K, Komori A, Ito M, Shimoda S, Nakamura H, Nagaoka S, Abiru S, Migita K, Ishibashi H, Nakanuma Y, Nishida N, Kawashima M, Tokunaga K, Yatsuhashi H, Nakamura M (2014) Systemic and local expression levels of TNF-like ligand $1 \mathrm{~A}$ and its decoy receptor 3 are increased in primary biliary cirrhosis. Liver Int 34:679-688. https://doi.org/10.1111/liv.12296

72. Bamias G, Kaltsa G, Siakavellas SI, Papaxoinis K, Zampeli E, Michopoulos S, Zouboulis-Vafiadis I, Ladas SD (2010) High intestinal and systemic levels of decoy receptor 3 (DcR3) and its ligand TL1A in active ulcerative colitis. Clin Immunol 137:242249. https://doi.org/10.1016/j.clim.2010.07.001

73. Hitomi Y, Kawashima M, Aiba Y, Nishida N, Matsuhashi M, Okazaki H, Nakamura M, Tokunaga K (2015) Human primary biliary cirrhosis-susceptible allele of rs4979462 enhances TNFSF15 expression by binding NF-1. Hum Genet 134:737-747. https://doi. org/10.1007/s00439-015-1556-3

74. Kestilä M, Lenkkeri U, Männikkö M, Lamerdin J, McCready P, Putaala H, Ruotsalainen V, Morita T, Nissinen M, Herva R, Kashtan CE, Peltonen L, Holmberg C, Olsen A, Tryggvason K (1998) Positionally cloned gene for a novel glomerular proteinnephrin - is mutated in congenital nephrotic syndrome. Mol Cell 1:575-582. https://doi.org/10.1016/s1097-2765(00)80057-x

75. Devuyst O, Olinger E, Rampoldi L (2017) Uromodulin: from physiology to rare and complex kidney disorders. Nat Rev Nephrol 13:525-544. https://doi.org/10.1038/nrneph.2017.101

76. Manolio TA, Collins FS, Cox NJ, Goldstein DB, Hindorff LA, Hunter DJ, McCarthy MI, Ramos EM, Cardon LR, Chakravarti A, Cho JH, Guttmacher AE, Kong A, Kruglyak L, Mardis E, Rotimi CN, Slatkin M, Valle D, Whittemore AS, Boehnke M, Clark AG, Eichler EE, Gibson G, Haines JL, Mackay TF, McCarroll SA, Visscher PM (2009) Finding the missing heritability of complex diseases. Nature 461:747-753. https://doi.org/10.1038/natur e08494

77. Veissi S, Smeets B, van den Heuvel LP, Schreuder MF, Jansen J (2020) Nephrotic syndrome in a dish: recent developments in modeling in vitro. Pediatr Nephrol 35:1363-1372. https://doi.org/ 10.1007/s00467-019-4203-8

78. Matzaraki V, Kumar V, Wijmenga C, Zhernakova A (2017) The MHC locus and genetic susceptibility to autoimmune and infectious diseases. Genome Biol 18:76. https://doi.org/10.1186/ s13059-017-1207-1
79. Raychaudhuri S, Sandor C, Stahl EA, Freudenberg J, Lee HS, Jia X, Alfredsson L, Padyukov L, Klareskog L, Worthington J, Siminovitch KA, Bae SC, Plenge RM, Gregersen PK, de Bakker PI (2012) Five amino acids in three HLA proteins explain most of the association between MHC and seropositive rheumatoid arthritis. Nat Genet 44:291-296. https://doi.org/10.1038/ng.1076

80. Morris DL, Taylor KE, Fernando MM, Nititham J, AlarcónRiquelme ME, Barcellos LF, Behrens TW, Cotsapas C, Gaffney PM, Graham RR, Pons-Estel BA, Gregersen PK, Harley JB, Hauser SL, Hom G, Langefeld CD, Noble JA, Rioux JD, Seldin MF, Criswell LA, Vyse TJ (2012) Unraveling multiple MHC gene associations with systemic lupus erythematosus: model choice indicates a role for HLA alleles and non-HLA genes in Europeans. Am J Hum Genet 91:778-793. https://doi.org/10.1016/j.ajhg. 2012.08.026

81. Stanescu HC, Arcos-Burgos M, Medlar A, Bockenhauer D, Kottgen A, Dragomirescu L, Voinescu C, Patel N, Pearce K, Hubank M, Stephens HA, Laundy V, Padmanabhan S, Zawadzka A, Hofstra JM, Coenen MJ, den Heijer M, Kiemeney LA, Bacq-Daian D, Stengel B, Powis SH, Brenchley P, Feehally J, Rees AJ, Debiec H, Wetzels JF, Ronco P, Mathieson PW, Kleta R (2011) Risk HLADQA1 and PLA(2)R1 alleles in idiopathic membranous nephropathy. N Engl J Med 364:616-626. https://doi.org/10.1056/NEJMo a1009742

82. Beck LH Jr, Bonegio RG, Lambeau G, Beck DM, Powell DW, Cummins TD, Klein JB, Salant DJ (2009) M-type phospholipase A2 receptor as target antigen in idiopathic membranous nephropathy. N Engl J Med 361:11-21. https://doi.org/10.1056/NEJMo a0810457

83. Topham PS, Kawachi H, Haydar SA, Chugh S, Addona TA, Charron KB, Holzman LB, Shia M, Shimizu F, Salant DJ (1999) Nephritogenic mAb 5-1-6 is directed at the extracellular domain of rat nephrin. J Clin Invest 104:1559-1566. https://doi.org/10. 1172/jci7728

84. Watts AJB, Keller KH, Lerner G, Rosales I, Collins AB, Sekulic M, Waikar SS, Chandraker A, Riella LV, Alexander MP, Troost JP, Chen J, Fermin D, Yee JL, Sampson MG, Beck LH, Jr., Henderson JM, Greka A, Rennke HG, Weins A (2021) Discovery of autoantibodies targeting Nephrin in minimal change disease supports a novel autoimmune etiology. J Am Soc Nephrol. https://doi. org/10.1681/ASN.2021060794

85. Musante L, Candiano G, Bruschi M, Santucci L, Carnemolla B, Orecchia P, Giampuzzi M, Zennaro C, Sanna-Cherchi S, Carraro M, Oleggini R, Camussi G, Perfumo F, Ghiggeri GM (2005) Circulating anti-actin and anti-ATP synthase antibodies identify a sub-set of patients with idiopathic nephrotic syndrome. Clin Exp Immunol 141:491-499. https://doi.org/10.1111/j.1365-2249.2005. 02862.x

86. Jamin A, Berthelot L, Couderc A, Chemouny JM, Boedec E, Dehoux L, Abbad L, Dossier C, Daugas E, Monteiro RC, Deschênes G (2018) Autoantibodies against podocytic UCHL1 are associated with idiopathic nephrotic syndrome relapses and induce proteinuria in mice. J Autoimmun 89:149-161. https://doi. org/10.1016/j.jaut.2017.12.014

Publisher's Note Springer Nature remains neutral with regard to jurisdictional claims in published maps and institutional affiliations. 